\title{
EFFECT OF STATE COURT DECREES IN FEDERAL TAX LITIGATION: A PROPOSAL FOR JUDICIAL REFORM
}

The 1934 decision of the United States Supreme Court in Freuler v. Helvering ${ }^{1}$ created a controversy as yet unresolved. ${ }^{2}$ The issue in the Freuler case was the effect of a decree of a California state court purportedly resolving a property dispute affecting federal tax liability. The state court had determined that income paid to life beneficiaries under a trust properly should have been reserved to remaindermen as a depreciation allowance. Prior to this adjudication, the Commissioner of Internal Revenue had issued a deficiency notice to a life beneficiary for failing to include the allowance as income in her federal tax returns. ${ }^{3}$ While the taxpayer's appeal was pending before the Board of Tax Appeals, the California decision was handed down. The Board considered itself bound by the state court judgment and therefore precluded from making an independent investigation of the property issue. Accordingly, it reversed the Commissioner. ${ }^{4}$ However, upon the Commissioner's appeal, the Ninth Circuit held that "no orders of the probate court, the effect of which would relate to what are deductions to be allowed under the national income taxing law, are conclusive and binding on the federal courts...."5

On appeal, the Supreme Court characterized the order of the probate court as an order governing distribution within section 219 of the Revenue Act 6 and rejected the Ninth Circuit's view that it could not control the federal courts. The Commissioner then argued that the state court judgment did not represent "an actual adjudication of the question involved."7 Rather, the decree was "nothing more than a friendly settlement without any real contest, [requiring] the inference that the primary, if not the sole, object of the proceeding was to establish a basis for a deduction of depreciation for Federal income tax purposes."8 The Commissioner concluded that the California judgment, "collusively" obtained, fell without the category of state court decisions that must be followed by the federal courts in subsequent tax litigation. 9

1291 U.S. 35 (1934). Justices Cardozo, Brandeis and Stone dissented but accepted the majority finding on the issue which will be discussed in this paper.

2 See Northwest Security Nat'I Bank v. Welsh, 203 F. Supp. 263 (D.S.D. 1962).

3 The deficiency was determined under the Revenue Act of 1921, ch. 136, § 291, 42 Stat. 246. The current comparable section is INT. REv. CODE OF 1954, $\$ 641$.

4 Marguerite T. Whitcomb, 22 B.T.A. 188 (1931).

5 Commissioner v. Freuler, 62 F.2d 733, 735 (9th Cir. 1933).

6 Freuler v. Helvering, 291 U.S. 35, 43 (1934).

7 Brief for Respondent, p. 34, Freuler v. Helvering, 291 U.S. 35 (1934).

8 Id., pp. 34-35.

9 Fidelity \& Columbia Trust Co. v. Lucas, 52 F.2d 298, (W.D. Ky. 1931), rev'd on other grounds, 66 F.2d 116 (6th Cir. 1933). 
The Court accepted the government's position that a collusive state court decree would not bind the federal courts and defined a collusive proceeding as one in which "all the parties joined in a submission of the issues and sought a decision which would adversely affect the Government's right to additional income tax." 10 The problem of distinguishing collusive from regular proceedings was thus squarely presented.

However the Supreme Court held that the California proceedings were not collusive. The Court noted that: the state proceeding was usual,11 the probate court had jurisdiction over the subject matter, 12 notice was given to all interested parties, 13 objection to the account by the remaindermen provided the basis for deciding the tax issue,14 all parties were represented by counsel,15 and the decree was not "in any sense a consent decree."16 Although some ombination of these: actors compelled the conclusion that the state judgment bound the federal courts, 17 the Court made no attempt to assign evidentiary weight to the several factors noted, to define collusion or to indicate the policy reasons why collusively obtained judgments were excluded. As a result, Freuler was a decision on the facts which could give little guidance to lower courts when the factual situation differed.

Two years later, in Blair v. Commissioner, 18 the Supreme Court had an opportunity to resolve these ambiguities. The question in the Blair case involved the petitioner's right to assign income he received as a life beneficiary under a trust. In prior tax litigation, the Commissioner had argued that the trust in question was a spendthrift trust, with the result that the assignments were invalid and the income taxable to the petitioner. The circuit court, deciding the issue under Illinois law, found for the government after contested proceedings.19 Since the decision fixed Blair's tax liability only for the year 1923, he turned to the Illinois courts for favorable construction of the trust for subsequent tax purposes.

After obtaining a state appellate court judgment that the instrument was not

10 Freuler v. Helvering, 291 U.S. at 45.

$11 \mathrm{Ibid}$. The required trustee's account had been filed. $14 \mathrm{Ibid}$.

$12 I d$, at 38 .

15 Ibid.

13 Id. at 45.

16 Ibid.

17 The Court did not, however, mention certain factors noted by the Commissioner in his brief: that the "account" was the first rendered in more than twenty-five years and was filed during the pendency of the tax proceeding; that the answer of the remaindermen was filed two days after the filing of the account, although the remaindermen were resident in France; and that the account contained no information other than a statement of the aggregate of receipts and expenditures for each year. Brief for Respondent, p. 35, Freuler v. Helvering, 291 U.S. 35 (1934).

18300 U.S. 5 (1937).

19 Commissioner v. Blair, 60 F.2d 340 (7th Cir. 1932), cert. denied, 288 U.S. 602 (1933). 
a spendthrift trust,20 Blair disputed the Commissioner's assessment for the years 1924-1926 and 1929. The Board of Tax Appeals held that it was bound by the state decision intervening between the earlier federal litigation ${ }^{21}$ and the controversy before it.22 It was, however, reversed on other grounds by the Seventh Circuit. ${ }^{23}$ The taxpayer's appeal to the Supreme Court gave the Commissioner the opportunity to present the argument, overruled below, that the state court proceedings were collusive. 24 The Court ignored this chance to clarify the subject and dismissed the contention on the authority of Freuler.25 The opinion reiterated certain of the determinative factors in Freuler, adding that the Illinois court was aware of the prior tax proceedings. ${ }^{26}$ Again, the Court failed to discuss policy issues or precisely to define "collusion."27

Although lacking in guidance, Freuler and Blair are the final words of the Court. 28 The circuits were informed that a decision by a state court of com-

20 Blair v. Linn, 274 Ill. App. 23 (1934). It is strongly suggested by one commentator that this state proceeding was merely of "surface regularity." Cardozo, Federal Taxes and the Radiating Potencies of State Court Decisions, 51 YALE L.J. 783 (1942). See also Colowick, The Binding Effect of a State Court's Decision in a Subsequent Federal Income Tax Case, 12 TAX L. REV. 213, 234 (1957).

21 Commissioner v. Blair, 60 F.2d 340 (7th Cir. 1932), cert. denied, 288 U.S. 602 (1933).

22 Edward T. Blair, 31 B.T.A. 1192 (1935).

23 Commissioner v. Blair, 83 F.2d 655 (7th Cir. 1936). Although the court felt itself bound by the state decree, it went on to hold that the taxpayer's interest was limited to income and did not attach to the corpus of the estate. His interest could not, therefore, be transferred, and the "assignment" was merely petitioner's "direction to the trustees to pay [to the assignees], out of the income due to him, various specified amounts each year." Id. at 662. (Emphasis in original.)

24 "The Government is largely helpless if its revenues are to be put at the mercy of arrangements substantially inter partes in cases like this one. The Government is never made a party in submitting these controversies to the state courts; it could not be made a party. As a matter of fact, it is not ordinarily even notified of the proceeding. In the proceeding before the Illinois courts... there was no real dispute between the parties-the present petitioner and his assignees. They were in complete accord and agreement. So far as the parties to the case were concerned, the issue was largely feigned and moot. It was the Government's interest which was substantially affected by the decision, and yet the Government had no day in court, no opportunity to present the arguments opposed to those advanced by the parties before the court. ... Unless the Government's rights in these cases are to be put at the mercy of decisions had without allowing it a hearing, the state court decree in this case should not be a given conclusive effect." Brief for Respondent, pp. 19-20, Blair v. Commissioner, 300 U.S. 5 (1937).

25 Blair v. Commissioner, 300 U.S. at 10.

26 Ibid.

27 See Berger, Tax Consequences of Non-Tax Proceedings, 17 N.Y.U. 7th INST. ON FED. TAX 87, 104-05 (1959).

28 The Supreme Court has denied certiorari in subsequent collusion cases, in spite of the increasing discord among the circuit courts. See, e.g., Saulsbury v. United States, 199 F.2d 578 (5th Cir. 1952), cert. denied, 345 U.S. 906 (1953); Falk v. Commissioner, 189 F.2d 806 (3rd Cir.), cert. denied, 342 U.S. 861 (1951); Consumer-Farmer Milk Cooperative v. Commissioner, 186 F.2d 68 (2d Cir. 1950), cert. denied, 341 U.S. 931 (1951); Sharpe v. Commissioner, 107 F.2d 13 (3rd Cir. 1939), cert. denied, 309 U.S. 665 (1940). 
petent jurisdiction determines the character of property rights for federal tax purposes, 29 provided the decision is arrived at in "non-collusive" proceedings. ${ }^{30}$ Since no general rules were formulated, the circuits have been forced to develop their own criteria to identify collusive proceedings in the state courts.

This situation has resulted in circuit conflict. The First, Fifth, Seventh and Tenth Circuits usually scrutinize state court decisions and have characterized as "collusive" or "non-adversary" 31 many which superficially meet the tests of Freuler and Blair. 32 The Second, Third and Eighth Circuits have been more hospitable to state decrees rendered in proceedings of dubious adversary character. ${ }^{33}$ The remaining circuits have not taken an ascertainable stand; the Ninth Circuit tends to follow the strict, the Fourth and Sixth the liberal approach. 34

\section{The Criteria In the Circuit Courts}

Few of the circuits have attempted to reach the central issue, the definition of collusion. ${ }^{35}$ However, this is a question which should be answered by the Supreme Court, since ten definitions of collusion are hardly more salutary than ten conflicting undefined approaches. A more serious problem is that the circuits have rarely considered the policy reasons for the collusion rule. Yet conscious analysis of the rationale for the exclusion would reduce, if not eliminate, the circuit conflict.

The central portion of this study will be concerned with an analysis and resolution of the several positions of the circuit courts. ${ }^{36}$ The analysis will

29 Uterhart v. United States, 240 U.S. 598 (1916).

30 Blair v. Commissioner, 300 U.S. 5, 10 (1936); Freuler v. Helvering, 291 U.S. 35, 45 (1934).

31 The term "non-adversary" has repeatedly been used by the circuits and appears to be as determinative against binding effect as the term "collusion." But cf. Gallagher v. Smith, 223 F.2d 218 (3rd Cir. 1955); Eisenmenger v. Commissioner, 145 F.2d 103 (8th Cir. 1944). Clear distinction between the two terms has not been drawn, but it is arguable that a proper approach would consider non-adversary proceedings to be of great evidentiary weight in determining the existence of collusion.

32 E.g., In re Sweet's Estate, 234 F.2d 401 (10th Cir. 1956); Channing v. Hassett, 200 F.2d 514 (1st Cir. 1952); Loggie v. Thomas, 152 F.2d 636 (5th Cir. 1945); Brainard v. Commissioner, 91 F.2d 880 (7th Cir. 1937).

33 E.g., Gallagher v. Smith, 223 F.2d 218 (3rd Cir. 1955); Kelly's Trust v. Commissioner, 168 F.2d 198 (2d Cir. 1948); Eisenmenger v. Commissioner, 145 F.2d 103 (8th Cir. 1944).

${ }^{34}$ E.g., Pitts v. Hamrick, 228 F.2d 486 (4th Cir. 1955); Newman v. Commissioner, 222 F.2d 131 (9th Cir. 1955); Goodwin's Estate v. Commissioner, 201 F.2d 576 (6th Cir. 1953). The issue is never presented in the District of Columbia Circuit where property rights are adjudicated according to federal law.

35 But see Saulsbury v. United States, 199 F.2d 578, 580 (5th Cir. 1952), where the court defined a collusive proceeding as one in which "there was no genuine issue of law or fact... and no bona fide controversy between the [parties] as to property rights."

36 No attempt will be made here to deal with two related questions: (1) The reasons why state court judgments should have any effect on subsequent tax proceedings; the validity of the Uterhart rule is here assumed. But see Berger, supra note 27, at 104, where the author states that the doctrine may be attributable to an "intention of Congress to have state court 
reveal the difficulty of adjudicating collusion questions without referring to the end attained by excluding collusively obtained judgments. That end is the elimination of a device that prevents the Commissioner from presenting his theory of tax liability to a court. In the confused lines of circuit cases, and perhaps even in Freuler and Blair, 37 taxpayers have been able to frustrate the Commissioner by pro forma adherence in the state court to the Freuler criteria. ${ }^{38}$

For example, a beneficiary will seek to have an instrument construed with favorable tax consequences in a proceeding where he is not opposed by the Commissioner seeking a construction favorable to the government. To avoid this confrontation, the taxpayer will petition a state court where he need only assure that the proceeding looks like a regular proceeding without, in fact, being a contest. Discussion of the tax problem with other beneficiaries whose interests will be substantially unaffected by the adjudication is the next step. With their agreement to act as nominal adversaries, the "controversy" is ready for adjudication. Various procedural trappings, such as notice, briefs, oral argument and even an appeal, may be employed to create the flavor of adversary proceedings without presenting the substantive construction urged by the Commissioner. This fabricated aura of "adverseness" in the state proceedings ${ }^{39}$ will usually be sufficient to frustrate the Commissioner, since it will be difficult for him to sustain the burden of proving collusion. 40

decisions accepted" or to the fact that "due process, the Sixteenth Amendment or some other constitutional provision" requires their acceptance. See also Colowick, supra note 20 , at 229, who suggests that there are two reasons for the rule: (a) that the state court has peculiar knowledge of the local law and that its judgment is deserving of respect as a state court precedent; and (b) that unfairness will result to the taxpayer who is liable for taxes on benefits that he has not received due to the state court adjudication. But see the author's critique of these reasons, $i d$. at 229-30. See also Cardozo, supra note 20, at 786, relating the collusion rule to Erie R.R. Co. v. Tompkins, 304 U.S. 64 (1938). (2) The problems involved in distinguishing state court decisions conclusive in the federal courts because they adjudicate property rights from those which can have no effect on federal court decisions since they attempt to adjudicate rights in an area in which Congress has proposed its own criteria of taxability. See 1 PaUL, FEDERAL EstaTe AND GIfT TAXATION \&1.11 (1942), noted in Gallagher v. Smith, 223 F.2d 218, 221-23 (3rd Cir. 1955).

${ }^{37}$ See Cardozo, supra note 20; Colowick, supra note 20.

${ }^{38}$ See text accompanying notes 11-15 supra. Berger's article, supra note 27, is, in part, an intriguing handbook of tax avoidance through procedural placation.

39 The preservation of family harmony among beneficiaries of a family trust will also induce agreement among parties to a state suit. See Berger, supra note 27, at 105. In Gallagher v. Smith, 223 F.2d 218, 225 (3rd Cir. 1955), the Third Circuit stated that the preservation of family harmony was to be encouraged, and that, therefore, a state suit settled amicably by family members ought not to be disturbed. See also Bartol v. McGinnes, 185 F. Supp. 659, 661 (E.D. Pa. 1960).

40 Brodrick v. Gore, 224 F.2d 892 (10th Cir. 1955); Helvering v. Rhodes' Estate, 117 F.2d 509 (8th Cir. 1941); Steele v. United States, 146 F. Supp. 316 (D. Mont. 1956). But cf. Saulsbury v. United States, 199 F.2d 578, 580 (5th Cir. 1952), for a minority view placing the burden of proof on the taxpayer. 
Such unwarranted results are often dictated by the tests which the circuits have developed from Freuler and Blair. The indicia of collusion developed from those cases are directed solely to compliance with the procedural formalities of adversary proceedings. There is, however, no logical inference from the fact that procedural requirements have been met to a conclusion that the substantive issue has been argued on its merits.

The basis of circuit conflict is, for the most part, a difference of opinion about the effect of various procedures, since the courts have failed to ask whether substantive issues have in fact been argued.41 $\mathrm{A}$ discussion of the criteria developed by the circuits will show this. The circuit cases may be separated into those concerned with each of four circumstances: (1) the non-binding character of certain types of state proceedings; (2) the jurisdiction of the state court; (3) the actions of the parties before the state court; (4) the holding of the state court itself.

\section{A. Nature of the State Proceedings}

The circuits have often indicated that judgments rendered in certain types of proceedings cannot under any circumstances bind the federal courts. Refusal to honor such decrees is based on a doubt that the judgment is the result of the regular submission of issues. 42

All agree that consent decrees do not bind the federal courts in tax proceedings. 43 The consent decree merely gives judicial fiat to a contractual arrangement among the parties. 44

Greater controversy exists as to state judgments said to be "in the nature of . . . consent decree[s]." 45 This is apparently the result of the circuits' charac-

41 But see Gallagher v. Smith, 223 F.2d 218 (3rd Cir. 1955) and Eisenmenger v. Commissioner, 145 F.2d 103 (8th Cir. 1944), for an interpretation of the collusion issue that does go to the heart of the matter. These two circuits apparently will not consider any proceeding to be collusive unless there is a showing of actual fraud. See Colowick, supra note 20, at 233.

42 See, e.g., Freuler v. Helvering, 291 U.S. 35, 45 (1934); Faulkerson v. United States, 301 F.2d 231 (7th Cir. 1962); Newman v. Commissioner, 222 F.2d 131, 136 (9th Cir. 1955); First Mechanics Nat'l Bank v. Commissioner, 117 F.2d 127, 129-30 (3rd Cir. 1940).

43 E.g., (3rd Cir.) Darlington v. Commissioner, 302 F.2d 693 (1962); (7th Cir.) Merchants Nat'l Bank \& Trust Co. v. United States, 246 F.2d 410 (1957); (10th Cir.) In re Sweet's Estate, 234 F.2d 401 (1956); (9th Cir.) Newman v. Commissioner, 222 F.2d 131 (1955); (2d Cir.) Kelly's Trust v. Commissioner, 168 F.2d 198 (1948); (8th Cir.) Botz v. Helvering, 134 F.2d 538 (1943).

44 As such, it effectively binds the parties but is not a judicial application of the law to a case or controversy. See 3 FREEMAN, JUDGMENTS $\$ 1350$ (5th ed. 1925).

${ }^{45}$ See, e.g., Gallagher v. Smith, 223 F.2d 218, 224 (3rd. Cir. 1955), where the Third Circuit, on the basis of a doubtful interpretation of Helvering v. Bullard, 303 U..S 297 (1938), held that it was bound by a state judgment in the nature of a consent decree because it is conclusive of the parties' property rights. Id. at 223. Cf. the reasons given by Colowick for giving a state court decree binding effect, supra note 36. But cf. Newman v. Commissioner, 222 F.2d 131 (9th Cir. 1955), where the Ninth Circuit held a judgment not binding because it was in the nature of a consent decree. 
terizing as a "consent decree" any decree shown to be collusive. Such "consent decrees" are indistinguishable from the judgments arrived at in superficially adversary proceedings. Conflict in this area is merely a restatement of conflict about the proper definition of collusion.

The Seventh Circuit excluded a state court judgment rendered in an ex parte proceeding in Faulkerson v. United States.46 After noting the ex parte character of the proceeding, the court stated that the lower state court was one of eighty-four of equal jurisdiction whose decisions do not bind each other. Furthermore, the decision was contrary to state law and Treasury regulations. The holding is based on a combination of these factors, and it is difficult to determine whether the ex parte character of the proceeding was alone sufficient to turn the tide against the taxpayer. This is indicative of the general problem resulting from failure to assign weight to factors tending to show collusion.

Arguably, the ex parte nature of the proceeding is sufficient in and of itself to vitiate use of the judgment. Such proceedings are brought at the instance and for the benefit of one party without notice to persons having adverse interests. An adjudication on the merits is foreclosed by the nature of the proceeding. It seems that the other circuits would follow the Seventh in this regard.

The circuits also agree that retroactive or nunc pro tunc decrees are not binding, but there appear to be two distinct lines of reasoning compelling this conclusion. The Eighth Circuit, in Straight's Trust v. Commissioner, 47 viewed reformation proceedings as a device to lessen the national income tax. However, the Second Circuit, in Daine v. Commissioner, 48 and the Tenth Circuit, in Sinopoulo v. Jones, 49 reasoned that a retroactive decree could not change the factual situation that had created the tax liability. As Colowick points out, the latter decisions hold that a "state court may not retroactively create or destroy rights ....,"50 but this line of reasoning is questionable. As a result of a retroactive judgment there is often a redistribution of taxable benefits. Moreover, rights are created and destroyed as effectively by a retroactive judgment as by any other type. 51

The retroactive proceeding does, however, provide opportunity for a taxpayer to "manufacture evidence of [his] intentions" 52 for purposes of tax litigation. The crucial issue for the federal courts is whether taxable benefits have, in fact, been reallocated by the judgment, and, if so, whether the judgment was rendered in a contested proceeding in which the Commissioner's

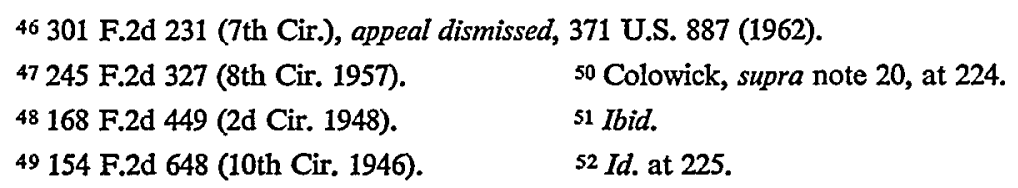


position was effectively argued and overruled. A nunc pro tunc decree is not, by its nature, conclusive proof of uncontested litigation.

The circuits also express some confusion as to declaratory judgments. No case holds that such a judgment is, by its nature, not binding in tax proceedings, but Loggie v. Thomas 53 and Sewell v. Commissioner 54 in the Fifth Circuit hesitated to follow such decrees, although their reasoning is not obvious. The Fifth Circuit's doubt is not shared by the Third, which, in Commissioner $v$. Thomas Flexible Coupling Co.,55 held a declaratory judgment binding. The Thomas decision is not the best possible authority since the court also emphasized that the judgment had been appealed to the state supreme court.56 The Second Circuit reached a similar result in Consumer-Farmer Milk Cooperative, Inc. v. Commissioner, 57 but without giving reasons or citing authority.

A declaratory judgment was recently held binding by a federal district court in Northwest Security Nat'l Bank v. Welsh, 58 because the state statute authorizing such suits stipulated that they must be based on a justiciable controversy between parties having adverse interests. ${ }^{59}$ However, compliance with such statutory terms is not a satisfactory criterion since that alone does not insure that the precise issue in the tax proceeding was fully contested in the state court. Conversely, there is no reason why any declaratory judgment should not be binding regardless of the statutory terms if the issue has been fully adjudicated with substantial presentation of the Commissioner's position.

\section{B. Jurisdiction of the State Court}

The second group of criteria used in the circuit cases concerns the jurisdiction of the state court. According to the Supreme Court, a decree of a state court of competent jurisdiction, absent proof of collusion, will bind the federal courts. ${ }^{60}$ However, the Seventh Circuit appears to have limited this doctrine. The court, in Brainard v. Commissioner 61 and Faulkerson v. United States, ${ }^{62}$ refused to honor decrees of lower state courts. ${ }^{63}$ In contrast, the

53152 F.2d 636 (5th Cir. 1945).

54151 F.2d 765 (5th Cir. 1945).

55198 F.2d 350 (3rd Cir. 1952).

56 Id. at 354. The court cited Kelly's Trust v. Commissioner, 168 F.2d 198 (2d Cir. 1948), for the proposition that an appeal makes a suit adversary whatever its nature might have been at its inception.

57 186 F.2d 68 (2d Cir. 1950). $\quad 58203$ F. Supp. 263, 266 (D.S.D. 1962).

59 The statute was the Uniform Declaratory Judgments Act. Section 6 of the Act gives the court discretionary power to refuse to enter a decree that would not terminate a controversy.

${ }^{60}$ Blair v. Commissioner, 300 U.S. 5 (1937); Uterhart v. United States, 240 U.S. 598 (1916).

6191 F.2d 880 (7th Cir. 1937), cert. granted, 302 U.S. 682, dismissed, 303 U.S. 665 (1938).

62301 F.2d 231 (7th Cir.), appeal dismissed, 371 U.S. 887 (1962).

63 In Brainard the state court was one of eighty-four courts of equal jurisdiction and in Faulkerson, one of approximately one hundred such courts. 
Fourth Circuit, in Pitts v. Hamrick, 64 stated that a decision of a probate court evidenced the law of the state even though no higher court had passed upon the question.

The Supreme Court has not explicitly indicated whether it favors limiting the broad doctrine of competent jurisdiction. 65 However, it is doubtful that the Seventh Circuit has offered a workable distinction. Since only state supreme courts have the final word on matters of state law, the logical conclusion of the Seventh's reasoning is that only decisions of those courts would be binding. This would not only work undue hardship on parties legitimately seeking to have property rights adjudicated by a state court, but also is contrary to the holding of the Supreme Court.66

\section{Actions of Parties Before the State Court}

The formal actions of the parties to the state suit supply the basis of the usual criteria developed by the circuits. This was not unexpected after Freuler, since that case emphasized the various components of regularity in the state court proceeding.

Although there is general agreement that a semblance of adversary proceedings must be shown, ${ }^{67}$ this is only the most general of criteria. It is necessary to look to its component parts to give the test content.

Freuler ${ }^{68}$ and numerous circuit decisions ${ }^{69}$ indicate that notice to all parties

64228 F.2d 486 (4th Cir. 1955).

65 The Court granted certiorari in Brainard, but the petition was dismissed on the motion of the petitioner. 303 U.S. 665 (1938). The Court's most definite statement to date may be found in Blair; the opinion declared that the fact that the state court was an intermediate court of appeal did not alter the binding effect of the judgment. Blair v. Commissioner, 300 U.S. 5, 10 (1937).

However, the Seventh Circuit's position seems to require the taking of an appeal at least to the intermediate level. The Supreme Court denied certiorari in Commissioner v. Sharpe, 107 F.2d 13 (3rd Cir. 1939), 309 U.S. 665 (1940), a Third Circuit case holding that an unappealed decision was binding.

${ }^{66}$ Blair v. Commissioner, 300 U.S. 5, 10 (1937).

${ }^{67}$ E.g., Stallworth v. Commissioner, 260 F.2d 760 (5th Cir. 1958); In re Sweet's Estate, 234 F.2d 401 (10th Cir. 1956); Pitts v. Hamrick, 228 F.2d 486 (4th Cir. 1955); Wolfsen v. Smyth, 223 F.2d 111 (9th Cir. 1955); Falk v. Commissioner, 189 F.2d 806 (3rd Cir. 1951). But cf. Gallagher v. Smith, 223 F.2d 218 (3rd Cir. 1955); Eisenmenger v. Commissioner, 145 F.2d 103 (8th Cir. 1944).

68291 U.S. 35 (1934).

69 See, e.g., Darlington v. Commissioner, 302 F.2d 693 (3rd Cir. 1962) (that all parties were summoned was a factor in denial of collusion); Faulkerson v. United States, 301 F.2d 231 (7th Cir.), appeal dismissed, 371 U.S. 887 (1962) (lack of notice in the ex parte proceeding relevant to determination of collusion); Goodwin's Estate v. Commissioner, 201 F.2d 576 (6th Cir. 1953) (notice cited as one of the factors determinative of lack of collusion); Henricksen v. Baker-Boyer Nat'l Bank, 139 F.2d 877 (9th Cir. 1944) (constructive notice sufficient where it is authorized). But cf. In re Sweet's Estate, 234 F.2d 401 (10th Cir. 1956) (notice insufficient to overcome fact that no party so notified contested the taxpayer's construction of a marital deduction trust); Channing v. Hassett, 200 F.2d 514 (1st Cir. 1952) (giving of notice not sufficient to overcome negative factors). 
in interest is desirable. Since the Commissioner is not an interested party, it is presently unnecessary that he be notified.70 The circuits have properly held that mere notice to the parties is insufficient to prove that the state proceedings were adversary. However, the absence of notice should create a strong presumption against the state decree. It may also be urged that the taxpayer, if he is aware of an impending tax controversy, should be required to notify the Commissioner as well as the parties of the pendency of the state suit. The Commissioner could then choose to present his view to those state courts that allow permissive intervention; 71 or file a brief as amicus curiae; or, if he chose not to argue, to study the proceedings closely for indications of collusion.72

Representation of the interested parties is akin to notice since it is not conclusive of contested litigation, 73 and its absence creates a strong presumption against the regularity of the state decree. 74 The presence of all interested parties should have little significance because the issue relates not to the presence of the parties but to the issues which they argued.

The filing of briefs, the presentation of oral argument and the contest of accounts in probate hearings have been frequently cited as indicia of adversary proceedings.75 However, the Third Circuit by its holding in Gallagher $v$. Smith that parties need not occupy adversary positions 76 has implied that it does not consider that such factors are necessary. ${ }^{77}$ All that Gallagher requires is an independent state court decision on a fairly presented issue.78 However, it is difficult to understand how such decisions may be obtained without a contest. "Fairly presented" implies that both sides are before the court; it

70 Eisenmenger v. Commissioner, 145 F.2d 103 (8th Cir. 1944).

71 This would confine direct intervention to those states that have followed Rule 24(b) of the Federal Rules of Civil Procedure. In those states, the Commissioner, authorized to enter state courts to protect the interests of the United States by 16 Stat. 162 (1870), 5 U.S.C. $\$ 316$ (1958), could intervene on the ground of a common question of law.

72 In 1947, the Commissioner indicated in a mimeograph that he did not favor interference in state suits, but he did not take a definite stand against all intervention. Mim. 6134, 4 CCH 1947 STAND. FED. TAX REP. $§$ 6137. A policy of intervention would, of course, create a large administrative burden for the Commissioner. See Colowick, supra note 20, at 232 .

73 E.g., In re Sweet's Estate, 234 F.2d 401 (10th Cir. 1956), where duly notified parties merely entered appearances but did not contest the suit. However, representation has been cited as a desirable factor, e.g., Darlington v. Commissioner, 302 F.2d 693 (3rd Cir. 1962).

${ }^{74}$ E.g., Faulkerson v. United States, 301 F.2d 231 (7th Cir.), appeal dismissed, 371 U.S. 887 (1962).

75 E.g., Freuler v. Helvering, 291 U.S. 35 (1934); Darlington v. Commissioner, 302 F.2d 693 (3rd Cir. 1962); Channing v. Hassett, 200 F.2d 514 (1st Cir. 1952).

${ }^{76} 223$ F.2d 218, 225 (3rd Cir. 1955).

77 See also Darlington v. Commissioner, supra note 76. But cf. Commissioner v. Childs' Estate, 147 F.2d 368, 370 (3rd Cir. 1945) (distinguished in Gallagher v. Smith, supra note 76, at 224).

78223 F.2d at 225 . 
cannot be assumed that judges will independently seek out arguments not introduced by counsel.

Even those circuits which require briefs, oral argument or contested litigation have not gotten to the crux of the problem. The content of the briefs or arguments and not the act of filing or presenting them should concern the federal courts 79 since the basic issue for them is whether the state court has passed upon the argument which the Commissioner urges in the later tax proceeding. If the decree is binding even if the state court has not done so, the Commissioner is deprived of his day in court. 80

The Third Circuit, in Falk v. Commissioner, ${ }^{81}$ and the Eighth Circuit, in Eisenmenger v. Commissioner, 82 have considered whether the taxpayer must familiarize the state court with the pending tax controversy. Neither circuit has found a duty to inform, but in Falk the court weighed the lack of notice to the court in deciding that the state judgment was not binding. Conversely, the Eisenmenger court considered the taxpayer's presentation of the record and briefs of prior tax proceedings among the factors pointing to regularity. Imposing a duty to familiarize the court with the tax controversy would tend to assure consideration of the merits of the tax issue. Furthermore, it would not burden the litigant who seeks a full adjudication of his rights.

The circuits do not agree about the effect of an unappealed decision. For example, in Third Nat'l Bank \& Trust Co. v. United States, 83 the First Circuit indicated by dicta that it might be bound by an unappealed probate court decree, although it had previously stated in Channing v. Hassett ${ }^{84}$ that the lack of an appeal was evidence of a collusive proceeding. Sharpe v. Commissioner 85 and Goodwin v. Commissioner 86 take the contrary view and hold unappealed decisions binding. 87 The First Circuit position seems more reasonable since it does not automatically eliminate from consideration all unappealed judgments, but rather finds in them a rebuttable presumption of irregularity. This brings the factor to the evidentiary level where it belongs.

A unique position was taken by the Second Circuit in Kelly's Trust $v$. Commissioner. ${ }^{88}$ The court there stated that the taking of an appeal is conclusive proof that the state proceeding was adversary. This is a wholly unwar-

79 The Third Circuit is, therefore, clearly correct in saying that these factors are no more than evidentiary. Ibid.

${ }^{80}$ See Cardozo, Federal Taxes and the Radiating Potencies of State Court Decisions, 51 YALE L.J. 783, 786 (1942).

81189 F.2d 806 (3rd Cir. 1951). $\quad 83228$ F.2d 772, 773 (1st Cir. 1956).

82145 F.2d 103 (8th Cir. 1944). $\quad 84200$ F.2d 514 (1st Cir. 1952).

85107 F.2d 13 (3rd Cir. 1939), cert. denied, 309 U.S. 665 (1940).

86201 F.2d 576 (6th Cir. 1953).

87 See also Mappes v. United States, 208 F. Supp. 42 (W.D. Okla. 1962); Stackpole v. Granger, 136 F. Supp. 382 (W.D. Pa. 1955).

88168 F.2dj198 (2d Cir. 1948). 
ranted conclusion. There is no reason why an appeal is any less likely to be pro forma than the original litigation, 89 especially if the taxpayer will still profit when the costs of the appeal are deducted from his eventual tax saving.

\section{Content of the State Court Holding}

The circuits have given some consideration to the substance of the state court decision. There is no difficulty in deciding that the state judgment is not binding when the issue in the tax controversy has clearly not been adjudicated. In Third Nat'l Bank \& Trust Co. v. United States, 90 for example, the First Circuit found that the Massachusetts probate court had merely announced a general principle of law applicable in the absence of facts pointing to a contrary result. The existence of such facts, however, constituted the issue in the tax controversy. Holdings that the state court never met the crucial issue also can be found in the Third, Fourth and Seventh Circuits. ${ }^{91}$

These decisions are correct, and it is unfortunate that they occur only in the clearest cases, since the taxpayer is usually clever enough to put the semblance of an issue before the state court.

\section{A Proposal for Revised Criteria}

This brief summary of the work of the circuit courts reveals a good deal of confusion and misdirection.92 In 1962, a federal district court, presented with the government's contention that a state court decree was collusively obtained, "admit[ted] to considerable uncertainty as to the present state of the law."93 Nevertheless, this uncertainty will not be resolved until the courts seriously consider the reason why decrees obtained by collusion are not conclusive in subsequent tax litigation. It is merely circular to argue that such judgments are not binding because they are non-adversary. The true reason for the collusion rule is the impropriety of preventing the government from presenting its theory to a court. Thus, only an adjudication on the merits will satisfy the collusion rule.

The simplest method of assuring a contest in tax cases is to exclude all state court judgments purporting to fix property rights affecting federal tax liability, although the Supreme Court has refused to accept this alternative. ${ }^{94}$ Therefore,

89 Thomas Flexible Coupling Co. v. Commissioner, 14 T.C. 802, 823 (1950) (dissent).

90228 F.2d 772 (1st Cir. 1956).

${ }^{91}$ Keating v. Mayer, 236 F.2d 478 (3rd Cir. 1956); Burton v. Bowers, 172 F.2d 429 (4th Cir. 1949); United States v. Mitchell, 74 F.2d 571 (7th Cir. 1934).

92 See 1 PaUl, Federal Estate and Gift Taxation \$1.11 (1942).

93 Northwest Security Nat'l Bank v. Welsh, 203 F. Supp. 263, 265 (D.S.D. 1962).

94 Freuler v. Helvering, 291 U.S. 35 (1934); Uterhart v. United States, 240 U.S. 598 (1916). Writers have also suggested that such a policy would work an undue hardship on taxpayers who legitimately seek to have their interest adjudicated by a state court and that there may be constitutional issues involved. See Colowick, The Binding Effect of a State Court's Decision in a Subsequent Federal Income Tax Case, 12 TAX L. REv. 213, 234 (1957); and note 36 supra. 
it cannot be assured that the Commissioner will be able to present his own argument to a court. The collusion rule should be implemented in such a way as to avoid this anomalous situation.

If a taxpayer, intending to avoid tax liability, 95 institutes a state suit, and if no interested party presents the argument urged by the Commissioner, then the state court judgment should be considered to have been collusively obtained.96 It is apparent that many of the criteria developed by the circuits could still be utilized if this view of the rule were taken, but a change of emphasis would be required. Representation of and argument by all interested parties should carry little weight themselves; rather, the interests which the parties represented, and the arguments they urged, as evidenced in the record of the state proceedings, should determine the decision of the federal court. Similarly, state court awareness of the tax controversy should be a factor only insofar as that awareness is followed by full consideration of the issue.

State proceedings which are, by their nature, inconsistent with the existence of contested litigation should be denied conclusiveness. This does not depart from the current position on consent decrees and ex parte proceedings. However, declaratory judgments and nunc pro tunc decrees should be excluded only if they are not contests on the merits. Taxpayers have the right to seek to have tax disputes settled in their favor, but the manner in which they do so must be scrutinized.

Certain innovations could assist the federal courts. Requiring taxpayers to acquaint the state court with the pendency of tax proceedings and to notify the Commissioner of the institution of the state suit 97 might narrow the present scope for collusive tactics. An even more important innovation would shift the burden of proof on the collusion issue from the government to the taxpayer. 98 Shifting the burden of proof would, however, require departure from the established doctrine that state court proceedings are presumed to be regular. It might be argued that a change in the law would deny state courts

95 The intent to avoid tax liability is a necessary component of collusion if that term is to retain its ordinary meaning. This raises a problem where the requisite intent is lacking but the state decree does not, in fact, reflect an adjudication of the tax issue on its merits. Is such a decree to be honored by the federal court because of respect due to the state court? Or are the policy scales to be tipped in favor of the Commissioner? Freuler and Blair, strictly construed, would require that the respect due the state court be vindicated in this case.

96 This conclusion should follow even if an adverse argument other than the Commissioner's is presented.

97 The most appropriate manner by which this duty might be imposed is through the Treasury Regulations. A statement by the circuit courts that failure to acquaint the state court with the tax controversy is evidence tending to show collusion would undoubtedly also produce the desired effect. More dubious is the possibility of legislative enactment of such a requirement as an amendment to the Internal Revenue Code.

98 See PaUr, op. cit. supra note 92, at 81; Berger, Tax Consequences of Non-Tax Proceedings, 17 N.Y.U. 7TH INST. ON FED. TAX 87, 115 (1959). 
due respect. However, the respect presently accorded them derogates from that due to a department of the federal government.99 The problem of tax avoidance by use of state decrees is probably sufficient to weight the scales in favor of the government, since the taxpayer's intent to deprive the national government of revenue through collusive proceedings shows disrespect for both the national government and the state court.

The suggestions offered here do not require radical departure from the current practice of the circuit courts. In most cases, only conscious adherence to the proposition that "the best test of the correctness of a decision is its ability to withstand attack by those adversely affected by it" 100 is required to reform this area of present uncertainty.

99 A similar conflict occurs where the state decree does not show fraudulent intent but nevertheless fails as an adjudication on the merits. See note 96 supra.

100 Cardozo, supra note 80, at 795. 